\title{
Psychosocial factors influencing the experience of sustainability professionals
}

\begin{tabular}{|r|l|}
\hline Journal: & Sustainability Accounting, Management and Policy Journal \\
\hline Manuscript ID & SAMPJ-09-2015-0080.R1 \\
\hline Manuscript Type: & Research Paper \\
\hline Keywords: & $\begin{array}{l}\text { environmental sustainability, psychosocial, organisation, coping, resilience, } \\
\text { effectiveness, motivation, cognition, identity, emotion, values }\end{array}$ \\
\hline \multicolumn{2}{|l}{} \\
\hline
\end{tabular}

\section{SCHOLARONE \\ Manuscripts}




\section{Abstract}

Purpose

The study seeks to gain insight into psychosocial factors influencing sustainability professionals in their work to lead by influencing and improving pro-environmental decision-making in their organisations.

\section{Approach}

Using Interpretative Phenomenological Analysis as a framework, the study enquires into the lived experience of sustainability professionals and leaders from the UK and Canada. The primary data source is semistructured interviews, analysed with frame and metaphor analysis.

\section{Findings}

Key psychosocial factors involved in participants' experience are identified, specifically psychological threat coping strategies, psychological needs, motivation and vitality, finding complex interactions between them. Tensions and trade-offs between competency, relatedness and autonomy needs and coping strategies such as suppression of negative emotion and 'deep green' identity are modelled in diagrams to show the dynamics. How these tensions are negotiated has implications for psychological wellbeing and effectiveness, as well as for pro-environmental cognition and behaviour.

\section{Implications}

The concepts and models presented in this paper may be of practical use to sustainability professionals, environmentalists and organisation leaders, for example in identifying interventions to develop inner resources, support authentic and effective action and disrupt maladaptive responses to ecological crisis.

\section{Originality/value}

The paper contributes insight to understanding of underlying processes shaping environmental cognition and behaviour, particularly in relation to psychological threat coping strategies and interacting factors. With a transdisciplinary approach, the methodology enables nuanced interpretation of complex phenomena to be generated, and addresses gaps in psychology and organisation studies sustainability research, with implications for the future study of sustainability leadership.

Keywords: psychosocial, organisation, environmental sustainability, coping, motivation, needs, values, emotion, identity, cognition, resilience 


\section{INTRODUCTION}

This paper draws upon insights from a study investigating psychosocial factors influencing the experience of sustainability professionals (Andrews, Fahy \& Walker 2016), and contributes to understanding of factors influencing responses to ecological crisis in organisational contexts.

In this paper 'psychosocial factors' refer to psychological processes interacting with social contextual forces to shape behaviour. 'Ecological crisis' means changes in environment that destabilise continued survival, and is the term used to describe the situation currently facing humanity (Crompton \& Kasser 2009; Cebellos et al 2015). The human response to ecological crisis has been grossly inadequate to date, with severe negative consequences for humans and other living beings increasingly likely (Ceballos et al 2015; Klein 2014; Foster 2015). This paper argues that developing understanding of psychosocial factors and how they influence environmental cognition and behaviour is critical for supporting appropriate and effective action. Yet this is an area that has been under-explored in both psychology and organisational studies literature.

Within organisational studies, research tends to take organisational, institutional and global levels of analysis (Sharma \& Starik 2002; Lülfs \& Hahn 2014). A related field where individuals are analysed more closely is leadership studies. At times, leadership research has drawn from psychology, often to critique assumptions within organisation and management (Felfe and Petersen 2007). The importance of drawing more widely from psychology in the development of our understanding of leadership is now recognised (Jackson and Parry, 2007). As we seek to understand leadership for sustainability in particular, we can therefore employ more insights from psychology. Importantly, therefore, within the discipline of $n$ psychology, there is relatively little research on the environmental behaviour of individuals in their organisational contexts: it tends to focus on individuals in other contexts such as in the home or as consumers (Stern 2000; 2011). Yet in industrialised societies, people spend most of their lifetime at work (Uzzell \& Räthzel 2009) and as Stern (2000 p410) points out, "individuals may significantly affect the environment through... influencing the actions of organizations to which they belong". Furthermore, sustainability research at the individual-level of analysis has also focused on cognition, behaviour, and interventions to change behaviour (Wright, Nyberg \& Grant 2012; Spence, Pidgeon \& Uzzell 2009). The underlying drivers of behaviour have tended to be overlooked (Bartlett 2011; Lertzman 2015; Norgaard 2006). The research participants were six environmental sustainability managers and leaders with formal roles with regard to environmental policy, strategy and practice. The organisations are in the UK and Canada in the public and third sectors in local government, social housing, credit union and health care. The research participants' work ranged from producing environment strategies and policies, delivering energy efficiency programmes to conserving habitats.

The study has three research questions:

1. What is the experience of sustainability professionals oriented to pro-environmental values of working to influence and improve pro-environmental practices in their organisations?

2. What psychosocial factors can be identified that influence the participants' enactment of proenvironmental values in their work? How do these factors interact as processes?

3. What are the consequences/implications of the findings for individual effectiveness in improving organisational environmental practices, otherwise known as leadership for sustainability?

In this paper key themes in participant experience are identified and an analysis of psychosocial factors affecting their motivation and effectiveness is offered, interpreted through the lens of psychological threat (e.g. Crompton \& Kasser 2009; Lertzman 2015), environmental identity (e.g. Clayton \& Opotow 2003) and self-determination theory (Deci \& Ryan 2000). The dynamics of interacting processes are modelled, highlighting tensions and feedback loops.

The findings show that these tensions arise as the participants' consciously and unconsciously seek to satisfy basic psychological needs of competency, autonomy and relatedness, and to cope with psychological threats that can be brought on by living and working in the context of ecological crisis. How these tensions are negotiated has implications for their psychological wellbeing and their effectiveness in achieving results, as well as for shaping the nature of their responses as either ecologically adaptive or maladaptive. For example, whilst positivity about achieving results is motivating, unrealistic optimism is maladaptive. Suppressing difficult emotions about ecological crisis is also maladaptive if prolonged. On the other hand, out-sourcing a threatened 'deep-green' identity to an external like-minded environmental partner could be an adaptive strategy. These findings enrich our understanding of the complex processes involved in environmental behaviour. 


\section{Identity and context}

It seems that identity is a key factor moderating the relationship between pro-environmental values and behaviour (Schultz et al 2005; Schultz \& Tabanico 2007). According to a study by van der Werff et al (2013), values need to be linked to the self in order to be influential in choices that are made. Clayton \& Opotow (2003) emphasises that identity is fundamental to understanding human relationship with the natural world.

A number of studies show that environmental identity or sense of self as part of and connected with nature is linked with pro-environmental behaviour (e.g. Clayton 2003; Mayer \& Frantz 2004; Nisbet, Zelenski \& Murphy 2009). Social identity theory states that people tend to show bias towards those they see as being part of their in-group and prejudice and discrimination to those they see as part of their out-group. Seeing nature as part of one's in-group or out-group is therefore regarded as a key factor influencing sustainable behaviour (Crompton \& Kasser 2009).

However, as Clayton (2003) reminds us, because we have different sources of identity, an environmental identity is not enough to ensure environmental responsibility: it has to be salient, and it has to motivate us to gain the knowledge we need to understand our impact on the environment (p60).

Identities are understood to be arranged hierarchically in the mind and the salience of a particular identity at any moment is dependent on context and on commitment to that identity (Zavestoski 2003; Clayton \& Opotow 2003). These multiple identities may be integrated and unified to varying extents. Kahn (2003) studied developmental aspects of identity formation. A sense of unity in identity at any given time Kahn says is due to underlying cohesion in cognitive structures, with transformations in the cognitive structures helping to create a sense of a changing identity over time. Self-Determination Theory (SDT) considers humans to 
have an inherent tendency toward growth development and integrated functioning (Deci \& Vansteenkiste 2004). There are ways of constructing narrative identity or self-concept that are more likely to support the growth-strivings and need satisfaction of the self, and ways of constructing the self-concept that will impede or distract from this.

In their study of identity in organisations with regard to sustainability managers engaging with climate change, Wright, Nyberg \& Grant (2012) find that this engagement challenges dominant and privileged discourses in the organisation of shareholder value and economic growth. Due to this conflicting discourse, sustainability specialists are situated in a contradictory space. They conclude that the possibility to politically influence the organisation is dependent on how the individual negotiates these conflicts and how they manage their identities. The authors also propose that the possibility to experience and present a coherent pro-environmental narrative identity is undermined by a "consumption-oriented and media-driven world based upon technological and (dis)connected relationships" (p.1453)

Studying ethical blindness in organisations, Palazzo et al (2012) find that the temporary loss or inability to see that one is deviating from one's values is context bound. They argue that the frame people use to interpret the world and to make decisions is strongly influenced by the contexts in which they make those decisions. Context, they find, can be stronger than reason, values and good intentions. It is proposed that the main driver of ethical blindness is fear: fear of being humiliated, marginalised, of not meeting others' expectations and so on (Palazzo \& Hoffrage 2014).

This brings us to consider one further factor that plays a significant part in shaping pro-environmental behaviour: how one deals with psychological threat.

\section{Coping with psychological threat}

The environmental challenge facing humanity is thought to pose a profound psychological threat for example existential threat, threat to the integrity and stability of self-identity, and threat to self-esteem by threatening life plans and subverting internalised expectations of the future, reminding us of the fact of our eventual death, and challenging the morality of our ecologically destructive or apathetic behaviours (Hamilton \& Kasser 2009; Crompton \& Kasser 2009; Weintrobe 2013; APA 2009).

The disequilibrium caused by psychological threat is stressful and unpleasant; the tendency is to attempt to alleviate stress and decrease negative emotions through defence mechanisms and coping strategies in order to return to baseline functioning as soon as possible (Cramer 1998). These responses are understood to be part of normal human development but as with any psychological function, a normal process may as Cramer 1998 says, come to serve pathological ends if overused or situationally inappropriate. And in terms of addressing environmental issues, defences and coping strategies may be adaptive or maladaptive (Crompton $\&$ Kasser 2009). There is often a fear that allowing oneself to feel despair, for example, will break us apart, that we will get stuck in a dysfunctional state. Despair, Macy (1993) says, is "tenaciously resisted because it represents a loss of control, an admission of powerlessness. Our culture dodges that by demanding instant solutions when problems are raised" ( $p 18)$.

Psychological threat is not a simple phenomenon. Interaction of psychological threat with other variables can lead to different outcomes. For example, existential threat tends to motivate people to seek to enhance their sense of self through prioritising extrinsic goals of material wealth and success, which could be interpreted as a maladaptive coping strategy in terms of increased consumerism. But Fritsche \& Häffner (2011) found that existential threat loses its negative effect on pro-environmental behaviour if one's self-identity as being part of nature is strong.

There is relatively little qualitative research on psychological threat responses to ecological crisis, and within the psychoanalytic field more generally it seems there is not much consensus about what is and is not a coping strategy (Cramer 1998; Skinner at al 2003).

Adaptive strategies have been defined as those that promote psychological adjustment and stimulate actions appropriate to the new reality (Crompton \& Kasser 2009; Macy \& Brown 2014). Examples are seeking information, engaging with and regulating emotions, and collaborative problem-solving and taking action.

Maladaptive strategies are those that work against this in some way. There has been much focus on the threat response of denial (e.g. Stoll-Kleeman et al 2001; Norgaard 2006) which is when facts are not allowed to be accepted in the conscious mind. Thoughts or feelings that would be upsetting if accurately perceived are negated, ignored or misrepresented (Cramer 1998). However, people may both deny and acknowledge facts at the same time but with different parts of the mind in a process known as disavowal 
(Randall 2013). Other maladaptive strategies include distortion of facts e.g. by reinterpretation, shifting responsibility, self-enhancement e.g. materialistic behaviour or self-protection, emotional avoidance through e.g. suppression, escapism, numbing and pleasure-seeking, Diversionary activity such as minor behaviour change and displaced commitment, resignation, passivity and other forms of non-action, wishful/magical thinking and unrealistic optimism, active catastrophism and self-destructive actions (Crompton \& Kasser 2009; Hamilton \& Kasser 2009; APA 2009; Weintrobe 2013; Hoggett 2011).

In advocating a psychoanalytic understanding of humans as 'conflicted beings with high capacity for contradiction', Lertzman (2015) places the focus of research on how conflicts and dilemmas are negotiated, supported and 'worked through' towards greater alignment and behavioural changes (p7).

Mindfulness has been proposed as a tool to help people respond in an adaptive way to psychological threat (Crompton \& Kasser 2009). This is because through practicing mindfulness, practitioners cultivate the ability to be aware of emotions, physical body sensations, thoughts, and sensory information, moment-by-moment. Emotions and body sensations are information, and attending to feedback signals is vital for self-regulation (Shapiro \& Schwartz 1999). Instead of reacting automatically to psychological threats, which may involve resisting or suppressing difficult emotions, practitioners learn to accept these emotions and ultimately work through them (Kabat-Zinn 1990). This is important because emotion plays an important role in directing attention and guiding behaviour (Stangor 2010; Deci et al 2015). And as explained by Rogelberg (2006) regulating strong negative emotion through suppression takes emotional and physical effort, which may affect the ability to think as cognitive resources are diverted away from other tasks. Cognitive functioning may also be impaired due to stress induced by dissonance between felt and expressed emotions.

Macy \& Brown (2014) insist that is precisely because we are interdependent and connected with nature that we feel pain about its destruction. It is in honouring this pain and accepting these emotions as legitimate indeed as appropriate responses, they argue, that we are better able to act adaptively in bringing the world towards ecological balance. Randall (2013) holds that it is this working through of difficult emotion that will bring the strength to make the personal, social and political changes that are needed.

Psychological threats can also be understood in relation to basic need satisfaction. Self-Determination Theory (SDT) is a macrotheory of human motivation that proposes humans have three basic psychological needs that require satisfying for psychological wellbeing: competency, relatedness and autonomy. These needs are drivers of behaviour. Deci \& Ryan (2000) define competency as feeling competent and efficacious, having an effect on the environment as well as attaining valued outcomes within it, engaging in optimal challenges and experiencing mastery of effectance in the world. Competency requires feedback, which can supportive or undermining of autonomy in the way it is given. Autonomy is defined as the desire to selforganise experience and behaviour and for activity to be concordant with one's integrated sense of self and intrinsic choices. Relatedness is seeking attachments and experiencing feelings of security, belongingness and intimacy with others. The extent and the manner in which these needs are satisfied have consequences for vitality and psychological wellbeing. The social context can either support or undermine needs satisfaction.

Bringing this discussion of theory back full circle to where it started with values, it has been suggested that mindfulness supports congruent enactment of values because in a mindful state, behaviours tend to be regulated autonomously in accord with chosen interests and values rather than socially derived forces or pressures (Brown et al 2007).

\section{Summary}

The literature introduced above demonstrates the complex nature of environmental behaviour, involving underlying drivers of values, identity, needs, mindfulness, emotion regulation and other psychological threat coping strategies. These factors interact in often unconscious processes (Vignoles et al 2011; Breakwell 1986; Willig \& Stainton-Rogers 2010). This means they are not as readily accessible to the conscious mind and are less easy to articulate directly than opinions (Swim et al 2011), which is perhaps the reason why opinions and intentions are researched more often. Psychology research into environmental behaviour tends to favour correlational and experimental approaches (Lertzman 2015; Willig \& Stainton-Rogers 2010), which do not lend themselves to investigating unconscious processes. Organisational studies of environmental behaviour rely on explanatory frameworks like Azjen's theory of planned behaviour that have been critiqued for assumptions about rationality and the narrow focus of variables considered (Kolmuss \& Agyeman 2002; Lorenzoni et al 2007; McDonald 2014). 
The methodology used in this study was designed to address these issues and get below the surface of descriptive accounts and conscious cognition.

\section{STUDY APPROACH}

The study focuses on six individuals with pro-environmental values who have formal roles in their organisation with regard to environmental policy, strategy and practice. One was a chief executive where such concerns are part of a broader responsibility, and the other five were environmental sustainability managers. The organisations were in local and regional government, social housing, credit union and hospital sectors in the UK and Canada. The table below provides some contextual information about each participant.

[Table 1 here]

\section{Recruitment, selection and ethics}

Research participants were recruited according to three key criteria: currently working in formal roles involving influencing environmental decision-making, holding strong pro-environmental values that motivate them to do this work, and propensity and willingness to be mindful (so that they would be able to give rich accounts of their subjective experience). This created some homogeneity in the sample.

A variety of local, national and global marketing channels were used to reach a wide number of sustainability professionals including mailing lists of professional bodies and sustainable business social networks, social media posts, and the researcher's personal and professional contacts. Basic information was provided via a link to a website but details of the theories underpinning the study were not revealed. Candidates were invited to complete an online survey that included questions about their organisation, role, motivation for taking part in the study, motivation for working in environmental sustainability sense of connection with nature, and mindfulness. Eight candidates that fitted the criteria and completed the survey were selected, of which six (three females and three males) ended up completing the full study over the course of one year.

A sample size of six participants is regarded as a sufficient for a qualitative study into lived experience using close detailed analysis of each case (Smith, Flowers \& Larkin 2009).

Ethical approval for the study was obtained prior to recruitment and all participants completed consent forms. The main ethical issues considered related to treatment of confidential or organisationally sensitive information, and sharing research findings with participants i.e. what information and how it is communicated. The latter is a central ethical question in psychosocial research, to which there are no easy answers (Clarke \& Hoggett 2009 p46). Fictitious names are used in this paper to protect the participants' anonymity, and other identifying information has also been removed.

\section{Data generation, analysis and interpretation}

The main method for generating data was semi-structured interviews but other sources such as participant diary, organisational documents, and indirect observation via audio recordings of meetings were also analysed, and a reflexive diary was kept by the researcher. The 2-hour interviews were audio recorded and transcribed verbatim. The aim of the interview was to obtain detailed accounts of the participants' lived experience of influencing their organisation. Topics included personal relationship with nature, views on the environmental situation, views on their organisation's environmental impact, their experience of influencing decision-making, and their experience of attending mindfully to their inner and outer experience during a significant event such as a strategy meeting.

Data was analysed using the framework of Interpretative Phenomenological Analysis (IPA) integrated with frame and metaphor analysis.

IPA is concerned with gaining insight into how someone experiences and makes sense of a given phenomenon. It takes a critical hermeneutic approach that allows for the development of alternative narratives beyond mere description, informed by extant theory, and also leaves space for both intuitive and intersubjective approaches to data analysis (Smith, Flowers \& Larkin 2009). The premise behind the critical hermeneutic stance is that people may not be consciously aware of all the processes involved in their behaviour and experience (Willig \& Stainton-Rogers 2010). 
After data analysis and interpretation, a final debrief conversation was held with the participants to share the theoretical framework for the study, which had not been disclosed to avoid unnecessary bias, and to share key findings as a stakeholder check for credibility and trustworthiness (Thomas 2006; Lincoln \& Guba 1985).

\section{Limits and epistemology}

In-depth qualitative research of this type with a small number of case studies is largely concerned with nuanced interpretation of lived experience that is situated in a specific context at a particular moment in time. The participants were from public and third sector organisations in the UK and Canada with English as a first language; none worked within the private sector or in non-Western societal contexts. This paper does not make any claims about the generalisability of the results of the study for a wider population, including in other industry sectors or in non-English speaking cultures, or for the applicability of the findings in all life domains.

The epistemological approach of IPA and cognitive linguistics (Johnson \& Lakoff 2002) is neither objectivism nor subjectivism. Individuals are essentially embedded, intertwined and immersed in the world, and meaning is generated through these ongoing embodied interactions (Johnson \& Lakoff 2002; Larkin, Watts \& Clifton 2006). This is also consistent with the psychosocial approach takes the view that psychic and social processes are always implicated in each other and cannot be studied separately in a meaningful way (Clarke \& Hoggett 2009). Objective assessments of the organisational context are therefore not relevant.

The study methodology involved the use of abductive reasoning and drew inferences from a small number of people with whom the researcher had fairly brief encounters. From a phenomenological perspective however this does not discount its validity, and there is potential for something meaningful, tangible and significant to be revealed (Larkin, Watts \& Clifton 2006). As a systemic and multifactor study there were also limits to the depth with which every factor could be studied. It presents a conceptual framework that can be used as the basis for further exploration.

\section{FINDINGS AND DISCUSSION}

The theory outlined above was used to guide data analysis and interpretation, which resulted in a narrative that should be understood as just one possible interpretation of the participants' experiences: it is not intended to represent an objective truth. However, debriefs with the participants confirm the interpretations that follow to be accurate, insightful and useful, to them at least. 
The study identified key psychosocial factors in participant experience, including how these factors interact as processes creating tensions and feedback loops. A diagram modelling these processes is used to structure this narrative, and the interpretation is grounded in the phenomenological evidence of extracts from participants' accounts (Smith, Flowers \& Larkin 2009).

Conflicts and tensions are a feature of human life (Searles 1972; Lertzman 2015), and have been found to be part of the experience of change agents in organisations (Wright, Nyberg \& Grant 2012; Meyerson \& Scully 1995). How these tensions are negotiated has implications for psychological wellbeing and effectiveness, as well as for pro-environmental cognition and behaviour. The ecological implications of coping strategies used by the participants are therefore considered.

In explaining this diagram, the first thing to note is the presence of self-reinforcing feedback loops between several of the factors. Arrows between items mean 'leads to' or 'influences'. These relationships can be supportive or undermining in their influence on the subject, depending on how the processes manifest.

[Figure 1 here]

The factors labelled competency, autonomy and relatedness refer to basic psychological needs, as previously discussed. Competency has been placed at the centre because effectiveness in achieving environmental results was a key concern for the participants. With the financial pressures that most public and third sector organisations are under, proving one's worth to the organisation by delivering results is critical in order to keep one's job. Environmental work is not a statutory duty for local authorities in the UK.

Ash: These aren't the times when you can afford, just someone going around being the green conscience of the organisation you know, got to deliver results to justify your own existence really

The participants sought to achieve results through the process of influencing thinking and decision-making, which involves being in relationship. As shown earlier (see Table 2), relationship with the organisation is a key theme in participants' accounts, with a subtheme of (in)congruence between the individual's proenvironmental values and goals and those of the organisation. Incongruence may lead the individual to adopt coping strategies to deal with threat to competency and relatedness needs.

\section{Identity work}

One strategy is suppression of identity, specifically a 'deep green' identity in order to fit in with colleagues (relatedness needs) and conform to the dominant organisational culture. To be effective in influencing colleagues and senior managers, they consciously chose to project a particular image that they think conveys professionalism and credibility. This positive perception is likely to make the individual more effective in influencing their decision-making and consequently in achieving the results they want, thus satisfying competency needs. If this works, then the individual is likely to keep suppressing this identity, creating the larger self-reinforcing feedback loop linking the coping strategy with relatedness and competency as shown. The following extracts from Ash illustrate this strategy:

I think the idea of a kind of deep green where you get into an almost spiritual sense of it, of every species has its right to life and should be respected and so on um I have some sympathy with that view

I've made a priority in my role getting the ear of (senior executives) which requires get- being credible... so early days fresh out of university very clear I'm not going to wear sandals bring lentil sandwich to work and have a beard... So being seen as being credible and professional

So perceived threat to competency triggers a coping strategy that involves suppressing an identity that might jeopardise credibility. However it may not work with everyone in the organisation:

Ash: I could, I could call myself Ash Corporate, you know and I live at number 1 Corporate Street Corporate Town and I love doing corporate and just talk about- and he still wouldn't believe I was anything other than Friends of the Earth in residence and he's just got that despite my best efforts not to you know wear a green shirt and uh open toed sandals or try and speak with too much passion or emotion about why we need to act, which is why I find it difficult-because I so consciously shut that out 
This extract also indicates that suppressing identity takes conscious effort (best efforts, try, so conscious/y), which has implications for vitality (Rogelberg 2006).

Where there is high compatibility with the organisation, the need to suppress such an identity is not a particular issue because authentic expression would not affect their relationship with colleagues or damage perceptions about their professionalism and credibility. Heather was the only participant with high compatibility and congruence; she had chosen to join the organisation specifically for this reason. In her position as chief executive she says:

I'm trying to get an environment where em every single person can participate, they can contribute, they can be themselves

Suppressing an identity to which the subject has a level of commitment can have implications for autonomy need satisfaction because their sense of inner coherence may be diminished. This may trigger feelings of self-doubt.

Ash: Ah occasionally I wonder I think about it less now but occasionally sense of whether I did the right thing. Harking back to a sense, I was leaving university and I remember reading stuff by Jonathan Porritt... whether you can be part of the system and change it from within... And another view saying no it's like everything else that starts outside the system as a force for change all of these things they just get absorbed and you know you'd have been out there on the barricades and instead they've got you in a nice professional job sitting in an office maintaining the status quo broadly

Suppression involves sacrificing a part of oneself. The etymology of the term 'harking back' is interesting to consider. It originally referred to hounds returning along a track when the scent has been lost, till they find it again (OED Online 2015). Was the decision on leaving university to work 'within the system' the point when the full scent of inner coherence was last smelled?

Robin expresses low commitment to a 'deep green' identity that he appears to regard as incompatible with being pragmatic:

I'm not a deep green kind of person probably, I wouldn't describe myself as that. I'm probably relatively pragmatic and I'm pushing for the environmental side but also understand some of the other pressures and compromise on some of those things... I guess what I'm saying is hopefully through working with me they'll see that I'm not just going to force green ideas down their throat.

Robin's concern for a non-confrontational relationship with his colleagues is also expressed in this extract. The pragmatic compromise to which Robin refers can also be found in the accounts of other participants. For example:

Hazel: I've changed my approach to embrace that culture which moves slowly... so I can see that um I'm fine with the way that things are progressing. It's not the hill that I want to die on. They're going to move slowly, I will work at their pace

Yet suppression in order to fit in may not fully satisfy relatedness needs anyway. All the participants who had some incongruence with the organisation expressed a sense of isolation or being different. For example:

Ash: I work with lots of people across the organisation but their priority is saving a million quid for the Property budget or you know they'll do the carbon stuff but we're not peas in a pod or birds of a feather or anything you know so they're not really in the same place as me

Where relatedness was not satisfied sufficiently through work relationships, an alternative strategy of close relationships with external third sector partners or like-minded friends and social networks was adopted. With two participants, there also appeared to be an 'out-sourcing' of the suppressed identity to external partners who can be and do what they themselves feel unable to:

Rosemary: I have been able to generate much more influence because of that (partnership) and potentially feed some information out to allow people to come back in and say things on essentially my behalf

Ash: I work very closely with the (name of organisation deleted) on food and they're a bunch of real radical greens who you know their previous lives were arrested by police at road demos and stuff and very committed kind of purist very consciously ideologically driven whereas mine's more up in the attic a bit 
The finding that individuals may suppress an identity in service of relatedness and competency needs is consistent with Self-Determination Theory (SDT), which states that people tend to internalise the values and regulations of their social groups, facilitated by feelings of relatedness and competency (Deci \& Ryan 2000). Breakwell (1986) provides a similar explanation, stating that individual values cannot be independent of social stereotypes and that threat arises when the individual learns that a social position carries a negative social value. Suppression is a response type that targets the threatened identity and restructures identity to make it less of an object for potential harm (Breakwell 1986; Petriglieri 2011).

The salience of a pragmatic professional identity is echoed in Wright \& Nyberg (2015) who find a 'rational manager' to be one of the key identities enacted by sustainability managers in corporations: "Confronted by the discourses of 'professionalism' and 'productivity', they (some interviewees) found the identity of the rational manager not only more appropriate but also liable to prove politically effective in convincing others of the merits of pro-environmental action" (p131), however this study indicates the strategy of suppression may not be effective with everyone in the organisation. The association of the pragmatic professional identity with credibility is consistent with Ashforth \& Humphrey (1995) who explain that rationality has become institutionalised in the form of 'norms of rationality' such that organisations must at least publicly conform to these norms to be perceived as legitimate.

Compromise is discussed in literature on change agents (Wright, Nyberg \& Grant 2012; Meyerson \& Scully 1993). This literature highlights the risk of co-option for those to compromise in order to avoid isolation and marginalisation. This is clearly indicated in the extract from Ash who in expressing self-doubt shows that competency and autonomy needs are not fully satisfied by this strategy.

The importance of support from external partners is consistent with the literature on SDT. Weinstein \& Ryan (2011) report that many workers experience low need satisfaction on the job and that need satisfaction, especially relatedness, plays an important role in stress regulation.

\section{Emotion regulation}

Expression / suppression of emotion has been included with identity in the same part of the diagram because it is a coping strategy that works in a similar way. The research participants accepted the facts of ecological crisis, as might be expected of people working professionally in environmental sustainability and who are motivated by pro-environmental values. When asked to think about the natural world and the effect of human actions, they described emotions such as sadness, frustration, angry, worrying, overwhelmingly distressing, depressing, upset, gloomy, melancholy and deeply disturbing. These emotions are common responses (e.g. see Wright \& Nyberg 2015) however they tended to be suppressed in service of meeting competency needs. There seemed to be a fear that engaging fully with such difficult emotions would lead to dysfunction and an undermining of their effectiveness, which gives support to Macy's (1993) assertion that "we are afraid that we might break apart or get stuck in despair if we open our eyes to the danger (p31). It is also consistent with Ashforth \& Humphrey (1995) who state that in organisational contexts there is an assumption that rationality is required for accomplishing tasks and that emotions have disruptive effect on effectiveness.

Robin: I think the initial emotion is anger or frustration. But I try and not retain those feelings really because they're quite self-destructive... I try to remain positive... I try to find reasons to be optimistic

Ash: Emotions I suppose when I think about it which I try and avoid think- it's rare that I- it makes me feel sad. Uh... I think I just feel a sense of melancholy about it really... Um... I tend not to explore them or I think I've got them in a box in my head... so I don't think its particularly helpful to explore because its kind of disabling in a way really and disheartening. So I think I put it in a box in the attic

Ash: Generally I'm an optimist though, I need that otherwise I'd give up I think, so

Heather: I think negative emotions is is sort of it's healthy to feel a reaction to it but em I think it's trying to sort of then turn it into either a positive action or a way of dissipating that negative sensation in your body so you're not carrying carrying it too much, which I think makes you less effective because the more you worry and get tense em and feel unwell you cant do positive change can you, you cant make a difference so 
Jay: And I don't want to get distressed. I cant watch distressing programmes, habitat destruction or. I suppose that's what I've done really... Because I'm powerless to do anything about them and I put too much I've invested too much emotional energy in them in the past.

That suppression of emotion takes effort is indicated by use of the word try. This is consistent with the research on emotion (e.g. Rogelberg 2006). Disheartening is an interesting term, invoking not just a physical feeling in the body but also a weakening of resolve. The effort involved to suppress identity and emotion takes energy, which impacts on vitality - the available energy needed to act, with subsequent implications for effectiveness and competency need fulfilment. The extract from Jay indicates that feeling both distress about something and powerless to do anything about it is experienced as energy depleting. From a SDT perspective, needs satisfaction maintains or enhances vitality (Ryan \& Deci 2008). Randall (2013) suggests that powerlessness and distress is likely to trigger a defence reaction, which in Jay's case manifests as selective attention and emotional avoidance.

Emotional avoidance strategies may be beneficial in the short term in reducing stress but over longer time periods they are associated with poorer health (Weinstein \& Ryan 2011). Engaging with and working through difficult emotions about ecological crisis is considered an adaptive coping strategy (Macy \& Brown 2014; Crompton \& Kasser 2009; Randall 2013; Lertzman 2015). But the organisational context may not provide a safe container for holding these emotions:

Ash: (silence) how do I feel about it (in quiet voice) as local government officers it's all bashed out of us in our day job because what we feel about things is completely irrelevant its about what the business case is, and you know pragmatic

In this quote, the organisation is perceived as violently hostile (bashed out of us) to emotion. Expressions of negative or intense emotion in the workplace tend to be unacceptable and emotion is regulated by neutralising, buffering, prescribing or normalizing (Ashforth \& Humphrey 1995) In this extract emotion is regulated by prescribing what is socially acceptable, with low tolerance for emotional displays.

\section{Motivation and vitality}

To create personal meaning and greater inner coherence, which as discussed may have been undermined by identity suppression and compromise, the research participants tell themselves a story that justifies their experience. A story common to all was 'doing good' and 'making a difference'. As long as there is strong enough belief that this is the case, this story provides motivation to keep doing what they are doing and to withstand any pressures and stress. Consider these statements by Rosemary:

And then you know for me I'm working in the environment in an organisation that is doing exactly the opposite of what I believe to be right a lot of the time. And then trying to be the person that's dragging that up and changing it, it's just... oophh (sighs) why would you do that to yourself? (laughs) you know

I think I can make a difference and I think the people that we've got around us now we can make a difference, which is suppose is why I keep doing it

The more struggle I've had with what we're all doing and yeah the harder that's got the more determined I suppose I've got to want to do something about it

The question arises of what happens if the story collapses? As Rosemary herself appears to realise:

My worth is wrapped up in how successful I am about protecting the environment of the region. Risky! (laughs)

The diagram shows influences on vitality from organisational pressures and from the subjects' own personal values. For example:

Rosemary: I feel the full pressure of having a job where there is quite a lot of expectation around it

Rosemary: Being in the system and trying to alter it is energetically exhausting... maybe it (environmental strategy document) takes quite a lot actually of the personal energy that's going in not just from me but from other people within the sector trying to hold back this tide... Because I care about that (the environment) I want to do a really good job so the pressure is immense

These quotes clearly show how much energy and effort is going in to achieve competency, in an organisational context that as the earlier quote indicates is at odds with her personal values and beliefs. As Kaplan \& Kaplan (1989) say, 'to be effective in an environment that undermines compatibility requires 
considerable effort" (p186). A sense of working against a much larger and unstoppable force - holding back this tide - presumably increases the feeling of effort and mental fatigue.

Strategies for maintaining and enhancing vitality is critical for the participants in being effective in achieving results, for with depleted energy cognitive functioning is likely to be impaired (Rogelberg 2006).

Participants cited various ways they nourish and revitalise themselves. Common to all was going outside and being in natural places rich with wildlife. These experiences involve close observation and multisensory interaction with the natural world, recognising its intrinsic value. With these kinds of intimate embodied experiences, such appreciation is not just an intellectual abstract idea it is subjectively felt. These practices are located externally in a physical place and they stimulate internally a sense of mental spaciousness and emotional stability.

Jay: because working in the woods sometimes is incredibly relaxing because you're just at one with what you're doing and you're relaxing with it

There is a considerable body of research on the wellbeing benefits of nature connection (e.g. Kaplan \& Kaplan 1989; MIND 2007; Mayer et al 2009; Nisbet et al 2011; Ryan et al 2010). This is a fully embodied interactive sensory experience of being in the world:

Heather: when I feel most at peace, calmest and happiest is sort of being outside with some sort of natural environment. I think when I'm outside particularly if I'm sort of in the Lakes on a mountain I feel completely and utterly at one, you can almost feel like the earth beats I know that sounds a bit sort of em a bit odd but I when you can hear everything and you can sort of smell outdoor smells and you can sort of touch the grass I just feel completely at one with sort of the rest of the planet really, which is quite nice. Em it re-energises me, em gives me sense of peace, it just feels fantastic so that's why I try and get outside when I can

For some this activity also renews motivation - it reminds them why they are doing the work:

Rosemary: Tremendous sense of calm actually and starts to... give I don't know help me reflect... So its em yeah just going outside just being outside reminding me that's why I come and do this stuff because that's quite hard sometimes to you know well battling within a public organisation that's going through massive budget cuts and lots of pressure to do this quickly and we've got to do that, to just remember ok that's why I'm doing it out there um

This effect on motivation is in accord with literature that states that positive encounters with the natural world can strengthen environmental identity and intrinsic goals (Schultz 2000; Brown \& Kasser 2005; WWF 2011; Weinstein et al 2009).

However, this sense of connectedness with nature is not consistent and there are times when the participants feel closer to or more part of nature and instances when they feel more distant or detached. Sense of connection was more likely to be weaker in urban environments, when indoors, or when preoccupied with thoughts. It is outside the scope of this paper to explore factors that may be contributing to this inconsistency; this will be discussed elsewhere (e.g. see Andrews, Fahy \& Walker 2016).

\section{Adaptive and maladaptive coping strategies}

In the diagram and the discussion above, some of the key strategies used for coping with psychological threat have been identified: identity suppression, pragmatic compromise, emotional avoidance and suppression of felt emotions, construction and maintenance of a motivational story, and nature connection.

The adaptive and maladaptive outcomes of these strategies will now be considered.

a) 'Deep green' identity suppression

This strategy is in service of meeting competency and relatedness but the findings show the strategy does not necessarily work completely and is likely to leave some deficiency in satisfaction of relatedness needs, and may also affect inner coherence and thwart autonomy, creating conflict between needs satisfaction. Suppression also takes effort, which has implications for vitality. Given the link between environmental identity and behaviour, suppression of a 'deep green' identity is unlikely to motivate radical proenvironmental responses. From a SDT perspective, if an identity has been suppressed it is not integrated with other aspects of the self, and so is less likely to be experienced as coherent and autonomous, making associated behaviours less likely to be performed effectively and to persist over time (Osbaldiston \& Sheldon 
2003; Deci \& Ryan 2000). The 'out-sourcing' of the identity to external environmental partners could be an ecologically adaptive strategy if the organisation is receptive to being influenced by the external partner.

Reduced saliency of 'deep green' identity at the individual level allows the organisation to avoid ways of conceptualising human relationship with nature that might lead to uncomfortable realisations about current practices. Ultimately, a possible maladaptive consequence is that the strategy helps to relieve the organisation of the need to act and make radical pro-environmental changes.

\section{b) Pragmatic compromise}

Adaptation and compromise were adopted in order to achieve results in organisational contexts of incongruence of values and goals. But whilst compromise may help satisfy competency and to some extent autonomy needs, it may also have a negative impact on inner coherence and only partially satisfy relatedness, thus creating conflicts between needs. As illustrated with one participant, there is a risk of cooption by the organisation for change agents who compromise to satisfy relatedness and competency needs. This would make it an ecologically maladaptive coping strategy: it allows the organisation to avoid transformational changes, whilst at the same time mollifying guilt (Hamilton \& Kasser 2009).

\section{c) Emotional avoidance}

Negative emotions about ecological crisis were suppressed because they were perceived to be a threat to competency. in one case, the organisational context was not perceived as a safe container for expressing these emotions. There was evidence of effort being used to suppress the emotions, and this has implications for vitality and effectiveness. As has already been discussed, emotional avoidance is viewed in the literature as a maladaptive coping strategy. However, the strategies could have an ultimately ecologically adaptive dimension if it creates temporary mental space to retreat from the intensity of the experience of working in environmental sustainability, especially in an organisational context of incongruence. This retreat may be therapeutic in allowing for healing and restoration of vitality so that engagement with the work is possible without suffering burnout or illness caused by prolonged stress. The key word here is 'temporary' because at some point the emotion would need to be engaged with for healthy functioning. Barrett \& Gross (2001, cited in Brown \& Cordon 2009) argue that effective emotion regulation requires being able to accurately track ongoing emotional states and know when and how to intervene to alter those states as needed ( $p 70)$. Mindful awareness of mind-body feedback signals could help with judging when to retreat and how long to stay there (Deci et al 2015). When mindful, retreat is an intentional conscious choice not an automatic unconscious defence reaction.

If emotional avoidance is not temporary, then the organisation does not have to confront, accept, and engage with the difficult emotions associated with facing up to the reality of ecological crisis. Suppression of emotion at an organisational level is likely to work against development of adaptive practices. As Rust (2008) says: "when we block out our feelings we lose touch with the urgency of the crisis" (p160).

\section{d) Motivational story}

The participants' stories serve to enhance their inner coherence. Focussing on positive aspects of the work and being optimistic was an important feature of the story. This could be ecologically adaptive or maladaptive depending on whether the optimism is realistic or not. If it denies the reality of the speed and scale of the transformations needed, and instead allows changes in organisational practices to be minor, then it could be considered maladaptive (Foster 2015). In this situation the outcome for the organisation is that it is able to carry on with business more or less as usual.

e) Nature connection

Unlike the other coping strategies, this appears to be a straight forwardly adaptive response bringing restorative benefits at the personal level. Employees that are healthy and vital have greater capacity to cope with stress (Weinstein \& Ryan 2011) and avoid burnout. The outcome for organisations is adaptive if the strategies supports employees to be resilient and effective in influencing pro-environmental change. Nature connection could also serve to strengthen pro-environmental values and environmental identity, which is adaptive for the organisation if these values are enacted in decision-making. Organisations with employees with a pro-environmental orientation are more likely to take environmental concerns seriously (Spanjol, Tam \& Tam 2015). 


\section{CONCLUSION}

Through the process of in-depth qualitative enquiry into the lived experience of sustainability professionals, a rich and complex set of interrelating psychosocial factors have been identified that impact on the research participants' effectiveness in influencing pro-environmental change. In this paper, the processes of psychological threat coping strategies, psychological needs satisfaction, and ways of maintaining or enhancing vitality have been discussed, with tensions and trade-offs between these aspects of experience highlighted. How these tensions are negotiated has implications for the effectiveness of the participants in influencing their organisations with respect to pro-environmental decision-making, as well as for their own psychological wellbeing.

The diagram included in this paper highlights some key dynamics in these processes. Although representing aspects of experience in simplified form, it demonstrates the highly nuanced insight that can be generated from micro-discourse analysis and interpretation of phenomenological accounts of lived experience from a psychosocial perspective. Such a design is under-used in sustainability research yet it has the potential to make a significant contribution to our understanding of human cognition and the underlying drivers of behaviour.

Given that the field of leadership studies is increasingly exploring the matter of "purpose" (Kempster, et al 2011) and the field of sustainability leadership in particular is exploring how purpose can shaping organisational change (Bendell and Little, 2015), this paper makes specific contributions by exploring psychological dynamics of environmental managers. It brings new systemic insight to our understanding of the tensions that arise for sustainability managers in their work to influence organisational practices, types of coping they use to negotiate these tensions, and possible adaptive and maladaptive outcomes of these responses for the individual and the organisation. It also contributes new knowledge about how psychosocial processes interact. Psychology and organisational studies literature is reliant on rational explanatory frameworks such as the theory of planned behaviour. This means that models of environmental behaviour, no matter how integrative of past literature, are still limited in their scope of factors. They do not include emotions about ecological crisis and how they are regulated, environmental identity (sense of self as part of nature), needs or vitality (e.g. see Steg \& Vlek 2009; Reser \& Swim 2011; Whitmarsh \& O'Neill 2010; Gatersleben et al 2012; Norton et al 2014; Lülfs \& Hahn 2014; McDonald 2014; Ciorcirlan 2016). Literature on environmental behaviours in organisation does not acknowledge the important role of external environmental partners in needs satisfaction, nor nature connection as an adaptive coping strategy. The literature also tends to assess outcomes in terms of value to the organisation (e.g. Norton et al 2014; Hoffman 1993), rather than value to the natural world. This observation is also made by Ciorcirlan (2016) in her review of environmental workplace behaviour literature. It also approaches the subject from a perspective that is concerned with how the organisation can improve employee green behaviour (e.g. see Lülfs \& Hahn 2014; McDonald 2014), and not so much with how the individual can improve organisational behaviour. This paper therefore enriches these fields by broadening the scope of the debate to include other psychosocial factors and theoretical perspectives. The paper demonstrates how psychosocial factors are important for further understanding the practice of sustainability leadership and associated discourses.

This paper reports on the findings of a study of six cases, but it may be that the findings have wider relevance although this has yet to be tested. The study has only just scratched the surface of the complexity of environmental behaviour and its drivers, and further research to probe into each aspect would be useful.

The diagram could potentially have practical use as a diagnostic tool for sustainability professionals to help make sense of the tensions and conflict they are experiencing, and assist them in identifying points of intervention to flip a 'vicious circle' into a 'virtuous circle' and to support their negotiation of the tensions between needs and coping strategies in ways that are adaptive on both personal and ecological levels. Working in stressful organisational situations of low values congruence is not easy. One option is to leave out of frustration, tiredness or burnout and work somewhere more congruent, as one participant had already done and another subsequently did. However, the task of influencing change in organisations remains. The findings discussed here could help change agents to remain in their organisations, and keep healthy, vital and effective. Therefore, the diagram and the thinking it represents could be deployed in leadership development programmes that include sustainability matters or professionals (Bendell and Little 2015). It may also be helpful in efforts to understand and promote resilient in leadership (Southwick et al 2017).

With awareness of these psychosocial factors and how they may interact with each other, and by choosing to provide ourselves with sufficient inner resources to act effectively and authentically in disrupting 
pathological responses to ecological crisis, we can help instil new adaptive patterns at individual, organisational and societal levels.

\section{ACKNOWLEDGEMENTS}

The study has been conducted as part of a PhD degree with HighWire Centre for Doctoral Training at Lancaster University UK. HighWire is funded by the Research Council UK Digital Economy Theme.

\section{REFERENCES}

Andrews, N, Walker, S, \& Fahy K. (2016) Between intention and action: psychosocial factors influencing action on climate change in organisations. In Filho, W. F. (Ed) Innovation in Climate Change Adaptation. Springer

American Psychological Association. (2009) Psychology \& Global Climate Change: addressing a multifaceted phenomenon and set of challenges. American Psychological Association, USA.

Ashforth, B. \& Humphrey, R.H. (1995) Emotion in the workplace: a reappraisal, Human Relations, 48(2) pp. $97-125$

Bardi, A. \& Schwartz, S.H. (2003) Values and behaviour: strength and structure of relations. Personality and Social Psychology Bulletin, 29. 1207-1220.

Bartlett, D. ed. (2011) Going green: the psychology of sustainability in the workplace. Leicester: The British Psychological Society.

Bendell, J. and Little, R. (2015) Seeking Sustainability Leadership, Journal of Corporate Citizenship, Issue 60, 13-26.

Breakwell, G. ((1986) Coping with threatened identities, Methuen \& Co London

Brown, K.W. \& Cordon, S. (2009) Toward a phenomenology of mindfulness: subjective experience and emotional correlates. In: F. Didonna, ed. Clinical handbook of mindfulness. New York: Springer.

Brown, K.W. \& Kasser, T. (2005) Are psychological and ecological well-being compatible? The role of values, mindfulness and lifestyle. Social Indicators Research. 74(2). 349-368

Brown, K.W. et al. (2007) Addressing Fundamental Questions About Mindfulness. Psychological Inquiry. 18(4) 272-281.

Ceballos, G. et al. (2015) Accelerated modern human-induced species losses: Entering the sixth mass extinction. Science Advances. 1(5) e1400253

Ciocirlan, C.E. (2016) Environmental workplace behaviors: definition matters, Organization \& Environment, DOI: $10.1177 / 1086026615628036$

Clarke, S. \& Hoggett, P. (eds.) (2009) Researching beneath the surface: psycho-social research methods in practice. Karnac London

Clayton, S. (2003) Environmental identity, in Clayton, S. and Opotow, S. (eds.) Identity and the natural environment: the psychological significance of nature. MIT Press. 60-86

Clayton, S. \& Opotow, S. (eds.) (2003) Identity and the natural environment: the psychological significance of nature. MIT Press.

Clayton, S. et al (2015) Psychological research and global climate change, Nature Climate Change, 5 (July) pp.640-646

Cramer P. (1998) Coping and defense mechanisms: what's the difference? Journal of Personality 66(6) 919946

Crompton, T. \& Kasser, T. (2009) Meeting Environmental Challenges: the role of human identity. WWF-UK

Deci, E.L., \& Ryan R.M. (2000), The "what" and "why" of goal pursuits: Human needs and the selfdetermination of behaviour. Psychological Inquiry. 11. 227-268

Deci, E.L. et al. (2015) Being aware and functioning fully, in Brown, K.W. Creswell, J.D. \& Ryan, R.M. (eds.) Handbook of Mindfulness; theory, research and practice, The Guilford Press, New York USA. 112-129 
Deci, E.L. \& Vansteenkiste, M. (2004) Self-determination theory and basic need satisfaction: Understanding human development in positive psychology. Ricerche di Psichologia, 27. 17-3

Felfe, J. and Petersen, L.E. (2007) Romance of leadership and management decision making, European Journal of Work and Organizational Psychology, Volume 16, Issue 1, pp1-24.

Foster, J. 2015. After Sustainability. Routledge, London UK

Fritsche, I. \& Häfner, K. (2012) The malicious effects of existential threat on motivation to protect the natural environment and the role of environmental identity as a moderator. Environment and Behaviour 44(4) 570-590

Gatersleben, B., Murtagh, N. \& Abrahamse, W. (2012) Values, identity and pro-environmental behavior. Contemporary Social Science: Journal of the Academy of Social Sciences, DOI: $10.1080 / 21582041.2012 .682086$.

Hamilton, C. \& Kasser T. (2009) Psychological Adaptation to the Threats and Stresses of a Four Degree World [conference paper] Four Degrees and Beyond conference Oxford University 28-30 Sept

Hoffman, A.J. (1993) The importance of fit between individual and organisational culture in the greening of industry, Business Strategy and the Environment 2(4) pp. 10-18

Hoggett, P. (2011) Climate change and the apocalyptic imagination, Psychoanalysis, Culture \& Society. 16 (Sept) 261-275

Holmes, T. et al. (2011) Common Cause Handbook. PIRC, UK

Jackson, J. and Parry, K. (2007) A Very Short Fairly Interesting and Reasonably Cheap Book About Studying Leadership, Sage, UK.

Jenkins, J. et al. (2011) Energy Emergence: rebound \& backfire as emergent phenomena. Breakthrough Institute, USA

Johnson, M. \& Lakoff, G. (2002) Why cognitive linguistics requires embodied realism. Cognitive Linguistics, 13(3), pp.245-263.

Kabat-Zinn, J. (1990) Full Catastrophe Living. Delta

Kahn, P.H. (2003) The Development of Environmental Moral Identity in Clayton, S. and Opotow, S. (eds.). Identity and the natural environment: the psychological significance of nature. MIT Press. 113-134

Kaplan, R. \& Kaplan, S. (1989) The experience of Nature: a psychological perspective. Cambridge University Press, Cambridge USA

Kasser, T. \& Crompton, T. (2011) Limitations of environmental campaigning based on values for money, image and status [briefing paper] Available from valuesandframes.org (accessed 12 March 2013)

Kempster, S. et al (2011) Leadership as Purpose: Exploring the role of purpose in leadership practice, Leadership, Volume 7, No. 3, pp. 317-334.

Klein, N. (2014) This Changes Everything: capitalism vs. the climate. Simon \& Schuster, New York

Kollmuss, A. \& Agyeman, J. (2002) Mind the gap: why do people act environmentally and what are the barriers to pro-environmental behaviour? Environmental Education Research, 8(3) pp.239-260

Lakoff, G. \& Johnson, M. (1980) Metaphors We Live By. Chicago: University of Chicago Press.

Larkin M., Watts, S. \& Clifton, E. (2006) Giving voice and making sense in interpretative phenomenological analysis. Qualitative Research in Psychology, 3, pp.102-120.

Lertzman, R. (2015) Environmental melancholia: psychoanalytic dimensions of engagement. Routledge, East Sussex

Lincoln, Y. \& Guba, E. (1985). Naturalistic inquiry. Sage, Beverly Hills CA

Lorenzoni, I. et al (2007) Barriers perceived to engaging with climate change among the UK public and their policy implications, Global Environmental Change 17 pp.445-459.

Lülfs, R. \& Hahn, R. (2014) Sustainable behaviour in the business sphere: a comprehensive overview of the explanatory power of psychological models, Organizations \& Environment, 27(1) pp.43-64

Macy, J. (1993) World as Lover, World as Self. Parallax Press, Berkeley 
Macy, J \& Brown, M. (2014) Coming Back to Life. New Society Publishers

Mayer, F.S. \& Frantz, C.P. (2004) The Connectedness to Nature Scale, Journal of Environmental Psychology 24 503-515

Mayer, F. S. et al (2009) Why is nature beneficial? The role of connectedness to nature. Environment and Behavior, 41, pp.607-643.

McDonald, F. V. (2014). Developing an integrated conceptual framework of pro-environmental behavior in the workplace through synthesis of the current literature. Administrative Sciences, 4, 276-303.

Meyerson, D.E. \& Scully, M.A. (1995) Tempered radicalism and the politics of ambivalence and change. Organization Science, 6(5), pp.585-600.

MIND (2007) Ecotherapy: The Green Agenda for Mental Health. [report] London: MIND.

Nisbet, E.K., Zelenski, J.M. \& Murphy, S.A. (2009) The Nature Relatedness Scale, Environmental and Behaviour 41(5) 715-740

Norgaard, K.M. (2006) "People want to protect themselves a little bit": Emotions, denial, and social movement non- participation. Sociological Inquiry, 76(3), pp.372-396.

Norton, T.A. et al (2015) Employee green behaviour: a theoretical framework, multilevel review and future research agenda, Organization \& Environment, 28(1) pp.103-125

OED Online (2015) Oxford English Dictionary $2^{\text {nd }}$ rev. ed. [online] Oxford University Press [Accessed 3 June 2015].

Osbaldiston, R. \& Sheldon, K.M. (2003) Promoting internalized motivation for environmentally responsible behavior: A prospective study of environmental goals. Journal of Environmental Psychology, 23, pp.349-357.

Palazzo, G., Krings, F., \& Hoffrage, U. (2012) Ethical blindness. Journal of Business Ethics. 109(3) 323-338

Palazzo, G. \& Hoffrage U. (2014) Mindfulness and Moral Stretching Part I and II, Week 7 video 1 and 2. MOOC-UNIL Unethical Decision-Making in Organisations [course materials] Lausanne University Sep 2014.

Petriglieri, J.L. (2011) Under threat: responses to and the consequences of threats to individuals' identities, Academy of Management Review, 36(4) pp.641-662

Randall, R. (2013) Great expectations: the psychodynamics of ecological debt, in Weintrobe S. (ed.) Engaging With Climate Change: psychoanalytic and interdisciplinary perspectives. Routledge, Hove UK, 87102

Reser, J.P \& Swim, J.K (2011) Adapting to and coping with the threat and impacts of climate change, American Psychologist, 66(4) pp.277-289

Rogelberg, S.G. (ed.) (2006) Encyclopedia of Industrial and Organizational Psychology. Sage Publications, London UK

Rust, M. (2008) Climate on the couch. Psychotherapy and Politics International, 6(3) pp.157-170.

Ryan, R.M, \& Deci, E.L. (2008) From ego-depletion to vitality: Theory and findings concerning the facilitation of energy available to the self. Social and Personality Psychology Compass, 2/2, pp.702-717.

Ryan, R.M. et al (2010) Vitalizing effects of being outdoors and in nature. Journal of Environmental Psychology, 30, pp.159-168.

Schultz, P.W. (2000) Empathising with nature: the effects of perspective taking on concern for environmental issues. Journal of Social Issues, 56(3), pp.391-406.

Schultz, P.W, et al. (2005) Values and their relationship to environmental concern and conservation behaviour. Journal of Cross-Cultural Psychology, 36(4) pp.457-475

Schultz, P.W. \& Tabanico. J. (2007) Self, Identity and the natural environment. Journal of Applied Social Psychology, 37(6) pp.1219-1247

Searles, H.F. (1972) Unconscious processes in relation to the environmental crisis. Psychoanalytic Review 59(3) pp.361-374

Shapiro, S.L. \& Schwartz G.E.R. (1999) Intentional systemic mindfulness: an integrative model for selfregulation and health. Advances in Mind-Body Medicine. 15, pp.128-134. 
Sharma, S. \& Starik, M. (2002) Research in Corporate Sustainability. Edward Elgar Publishing

Sheldon, K.M. \& Kasser T. (2011) Americans Recommend Smaller Ecological Footprints When Reminded of Intrinsic American Values of Self-Expression, Family, and Generosity, Ecopsychology 3(2) 97-104

Skinner, E.A. et al (2003) Searching for the structure of coping: a review and critique of category systems for classifying ways of coping. Psychological Bulletin. 129(2) 216-269

Smith, J, Flowers P \& Larkin M. (2009) Interpretative Phenomenological Analysis: theory, method and research. Sage, London

Southwick, F.S et al (2017) Leadership and Resilience, in Marques, J and Dhiman, S. (Eds.) Leadership Today: Practices for Personal and Professional Performance, pp 315-333, Springer, USA.

Spanjol, J. et al (2015) Employer-Employee Congruence in Environmental Values: An Exploration of Effects on Job Satisfaction and Creativity, Journal of Business Ethics, 130, pp.117-130

Spence, A., Pidgeon, N. \& Uzzell, D. (2009) Climate change - psychology's contribution. The Psychologist, 22(2), pp.108-111.Stangor C. (2010) Introduction to psychology. $1^{\text {st }}$ Canadian edition. Available at $<$ https://opentextbc.ca/introductiontopsychology/ $\geq$

Steg, L. \& Vlek, C. (2009) Encouraging pro-environmental behaviour: an integrative review and research agenda, Journal of Environmental Psychology, 29, pp.309-317

Stern, P.C. (2000) Toward a coherent theory of environmentally significant behaviour. Journal of Social Issues, 56, pp.407-424

Stern, P.C. (2011) Contributions of psychology to limiting climate change. American Psychologist, 66(4), pp.303-314.

Stoll-Kleemann, S. et al (2001) The psychology of denial concerning climate mitigation measures: Evidence from Swiss focus groups. Global Environment, 11, pp.107-117.

Swim, J.K.et al (2011) Psychology's contributions to understanding and addressing global climate change. American Psychologist, 66, pp.241-250.

Thomas D. R. (2006) A general inductive approach for analyzing qualitative evaluation data. American Journal of Evaluation 27(2) 237-46

Uzzell, D., \& Räthzel, N. (2009) Transforming environmental psychology. Journal of Environmental Psychology, 29(3), pp.340-350.

van der Werff, E. et al. (2013) The Value of Environmental Self-Identity, Journal of Environmental Psychology 34(2013) 55-63

Vignoles, V.L. et al (2011) Introduction: towards an integrative view of identity. In: S.J. Schwartz et al. (eds.), Handbook of Identity Theory and Research, Springer

Weinstein, N. et al (2009) Can nature make us more caring? Effects of immersion in nature on intrinsic aspirations and generosity. Personality and Social Psychology Bulletin, 35(10), pp1315-1329.

Weinstein, N. \& Ryan, R.M. (2011) A Self-determination Theory Approach to Understanding Stress Incursion and Responses, Stress and Health, 27, pp.4-17

Weintrobe S. (ed.) (2013) Engaging With Climate Change: psychoanalytic and interdisciplinary perspectives. Routledge, Hove UK

Whitmarsh, L. \& O'Neill, S. (2010) Green identity, green living? The role of pro-environmental self-identity in determining consistency across diverse pro-environmental behaviours, Journal of Environmental Psychology, 30, pp.305-314

Willig, C., \& Stainton-Rogers, W. (2010) Introduction. In: C. Willig, \& W. Stainton-Rogers, eds., The SAGE handbook of qualitative research in psychology. London: SAGE Publications Ltd. pp. 1-13.

Wright, C. Nyberg \& Grant (2012) "Hippies on the third floor". Organization Studies. 33(11) pp.1451-1475

Wright, C. \& Nyberg D. (2015) Climate change, capitalism, and corporations: processes of creative selfdestruction. Cambridge: Cambridge University Press

WWF (2011) Natural Change: Catalysing leadership for sustainability, WWF Scotland. 
Zavestoski, S. (2003) Constructing and maintaining ecological identities: the strategies of deep ecologists in Clayton, S. and Opotow, S. (eds.). Identity and the natural environment: the psychological significance of nature. MIT Press. 297-316 


\section{Figure 1 Dynamics of interrelating factors affecting competency}

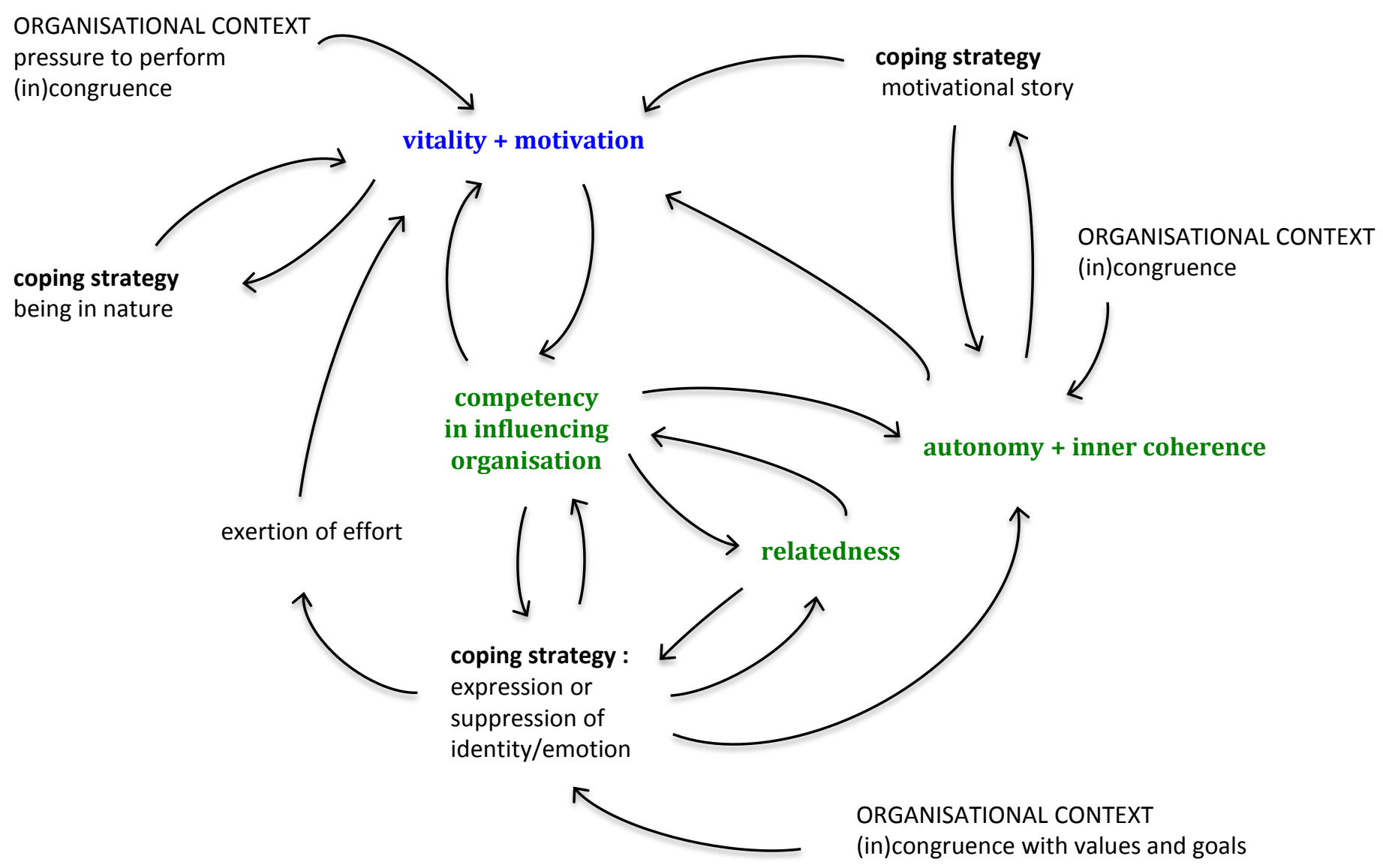


Table 1: Participant contextual information

\begin{tabular}{|c|c|c|}
\hline Pseudonym & Sector & Job title and role in organisation \\
\hline Rosemary & $\begin{array}{l}\text { Local } \\
\text { government } \\
\text { UK (public } \\
\text { sector) }\end{array}$ & $\begin{array}{l}\text { Strategic Environment Manager } \\
\text { Producing regional environmental strategy and influencing } \\
\text { decision-making about how natural 'assets' are devolved to } \\
\text { local government, in a context of severe cuts in public } \\
\text { funding. Seeking to protect these 'assets' from } \\
\text { 'irresponsible' decision-making of senior managers }\end{array}$ \\
\hline Jay & $\begin{array}{l}\text { Local } \\
\text { government } \\
\text { UK (public } \\
\text { sector) }\end{array}$ & $\begin{array}{l}\text { Ranger } \\
\text { Conserving and restoring nationally important habitat in a } \\
\text { context of major on-going organisational restucturing and } \\
\text { job losses as a result of severe cuts in public funding. } \\
\text { Seeking to ensure restructure does not adversely affect } \\
\text { effective site management }\end{array}$ \\
\hline Ash & $\begin{array}{l}\text { Local } \\
\text { government } \\
\text { UK (public } \\
\text { sector) }\end{array}$ & $\begin{array}{l}\text { Sustainability Manager } \\
\text { Delivering renewable energy programmes in the town and } \\
\text { influencing decision-making about 'greening' the town. } \\
\text { Seeking to reduce organisation's direct and indirect carbon } \\
\text { emissions and increase 'green infrastructure' }\end{array}$ \\
\hline Robin & $\begin{array}{l}\text { Social } \\
\text { housing UK } \\
\text { (third } \\
\text { sector) }\end{array}$ & $\begin{array}{l}\text { Environmental Sustainability Officer } \\
\text { Delivering energy efficiency programmes with social } \\
\text { housing residents and influencing decision-making about } \\
\text { building design. Seeking to reduce organisation's direct and } \\
\text { indirect carbon emissions and development on greenbelt } \\
\text { land and increase creation of wildlife habitats around their } \\
\text { properties }\end{array}$ \\
\hline Hazel & $\begin{array}{l}\text { Healthcare } \\
\text { Canada } \\
\text { (public } \\
\text { sector) }\end{array}$ & $\begin{array}{l}\text { Energy Steward } \\
\text { Leading programmes to reduce waste and energy use in } \\
\text { organisation. Seeking to reduce organisation's impact } \\
\text { through culture change }\end{array}$ \\
\hline Heather & $\begin{array}{l}\text { Credit Union } \\
\text { UK } \\
\text { (third } \\
\text { sector) }\end{array}$ & $\begin{array}{l}\text { Chief Executive } \\
\text { Ultimately responsible for organisation's activities, working } \\
\text { with Board to produce an environmental policy. Seeking to } \\
\text { reduce organisation's direct impact and its indirect impact } \\
\text { by financially supporting more environmental organisations }\end{array}$ \\
\hline
\end{tabular}


Table 2. Themes in participant experience

\begin{tabular}{|c|c|c|}
\hline $\begin{array}{l}\text { HIGHER } \\
\text { ORDER THEME }\end{array}$ & SUBTHEMES & ILLUSTRATIVE QUOTES \\
\hline \multirow{3}{*}{$\begin{array}{l}\text { Motivational } \\
\text { story }\end{array}$} & $\begin{array}{l}\text { Doing good, achieving results, } \\
\text { making a positive difference }\end{array}$ & $\begin{array}{l}\text { I like to think that I'm making a positive } \\
\text { difference towards my own beliefs in terms } \\
\text { of environmental issues and generally as well }\end{array}$ \\
\hline & Optimism, focus on positive & $\begin{array}{l}\text { If I think about it too much it gets a bit bleak } \\
\text { so I try and go, I try and go, "I'm doing good } \\
\text { things for the environment! }\end{array}$ \\
\hline & $\begin{array}{l}\text { Hero, Protector, Helper } \\
\text { narratives }\end{array}$ & $\begin{array}{l}\text { Can't be you know having my pants outside } \\
\text { my trousers (laughs) you know for the rest of } \\
\text { my days I'm holding the baton for the } \\
\text { environment }\end{array}$ \\
\hline \multirow{4}{*}{$\begin{array}{l}\text { Relationship } \\
\quad \text { with } \\
\text { organisation }\end{array}$} & $\begin{array}{l}\text { (In)congruence of values/goals } \\
\text { with organisation, }\end{array}$ & $\begin{array}{l}\text { I'm working... in an organisation that is doing } \\
\text { exactly the opposite of what I believe to be } \\
\text { right a lot of the time }\end{array}$ \\
\hline & Support, connection & $\begin{array}{l}\text { My immediate boss is very absent he's very } \\
\text { very involved in all sorts of other things so } \\
\text { we get very very little support }\end{array}$ \\
\hline & $\begin{array}{l}\text { Oppositional dynamic: fight, } \\
\text { competition, game, challenge, } \\
\text { conflict }\end{array}$ & $\begin{array}{l}\text { you know you wont win every battle, and } \\
\text { accept that you lose some }\end{array}$ \\
\hline & $\begin{array}{l}\text { Adaptation, compromise, } \\
\text { acceptance, prioritising goals }\end{array}$ & $\begin{array}{l}\text { I'm pushing for the environmental side but } \\
\text { also understand some of the other pressures } \\
\text { and compromise on some of those things }\end{array}$ \\
\hline \multirow[t]{3}{*}{ Identity salience } & $\begin{array}{l}\text { Expression, suppression, } \\
\text { projection of 'deep green' } \\
\text { identity }\end{array}$ & $\begin{array}{l}\text { The more they get to know me- well the } \\
\text { more I get to know me, the deeper green I'm } \\
\text { becoming! }\end{array}$ \\
\hline & $\begin{array}{l}\text { Credibility, professionalism, } \\
\text { pragmatism v 'deep green' } \\
\text { identity }\end{array}$ & $\begin{array}{l}\text { I'm not going to wear sandals bring lentil } \\
\text { sandwich to work and have a beard. So } \\
\text { being seen as being credible and professional }\end{array}$ \\
\hline & Reason-emotion duality & $\begin{array}{l}\text { It used to have a much more emotional } \\
\text { impact on me whereas now I'm a bit more - } \\
\text { slowly - I'm a bit more of a realist }\end{array}$ \\
\hline \multirow{2}{*}{$\begin{array}{l}\text { Engagement } \\
\text { with negative } \\
\text { emotions }\end{array}$} & $\begin{array}{l}\text { Suppression, avoidance of } \\
\text { negative emotion }\end{array}$ & $\begin{array}{l}\text { I think I probably try to repress a lot of those } \\
\text { emotions because doing the work that I do } \\
\text { you have to sort of stay optimistic and } \\
\text { hopeful }\end{array}$ \\
\hline & Reason-emotion dualism & $\begin{array}{l}\text { how do I feel about it (in quiet voice) as local } \\
\text { government officers it's all bashed out of us } \\
\text { in our day job because what we feel about } \\
\text { things is completely irrelevant it's about what } \\
\text { the business case is, and you know } \\
\text { pragmatic }\end{array}$ \\
\hline \multirow{2}{*}{$\begin{array}{l}\text { Mindful } \\
\text { awareness \& } \\
\text { embodied } \\
\text { cognition }\end{array}$} & Self-regulation & $\begin{array}{l}\text { I'm getting better at recognising when I feel } \\
\text { that sense of tension or worry, so if I can } \\
\text { recognise it I'll try to do something quickly } \\
\text { about it }\end{array}$ \\
\hline & Mind-body (dis)connection & $\begin{array}{l}\text { The desire is to move, like often it's to move } \\
\text { to bring it back into my body to allow it to } \\
\text { process but oft-uh it doesn't always allow it }\end{array}$ \\
\hline
\end{tabular}




\begin{tabular}{|c|c|c|}
\hline \multirow{3}{*}{$\begin{array}{l}\text { Tensions in } \\
\text { experience }\end{array}$} & $\begin{array}{l}\text { Experience of pressure, conflict, } \\
\text { struggle, difficulty etc. }\end{array}$ & $\begin{array}{l}\text { Because I care about that (environment } \\
\text { strategy) I want to do a really good job so } \\
\text { the pressure is immense }\end{array}$ \\
\hline & $\begin{array}{l}\text { Desire for wellbeing, comfort, } \\
\text { balance, support }\end{array}$ & $\begin{array}{l}\text { I've put too much effort into work because } \\
\text { I've needed to so I don't get any time at } \\
\text { home now. So that's a rebalance I need to } \\
\text { make }\end{array}$ \\
\hline & Coping strategies & $\begin{array}{l}\text { I'll go home and get drunk (laughs) to get } \\
\text { out the frustration }\end{array}$ \\
\hline \multirow[t]{6}{*}{$\begin{array}{l}\text { Relationship } \\
\text { with nature }\end{array}$} & Multi-sensory & $\begin{array}{l}\text { You can hear everything and you can sort of } \\
\text { smell outdoor smells and you can sort of } \\
\text { touch the grass }\end{array}$ \\
\hline & $\begin{array}{l}\text { Spiritual/transpersonal } \\
\text { experience }\end{array}$ & I feel completely and utterly at one \\
\hline & Restorative benefit & It gives me a sense of calm and wellbeing \\
\hline & Motivational & $\begin{array}{l}\text { Just being outside reminding me that's why I } \\
\text { come and do this stuff }\end{array}$ \\
\hline & $\begin{array}{l}\text { Appreciate intrinsic value of } \\
\text { nature }\end{array}$ & $\begin{array}{l}\text { When natural spaces are lost its sad that its } \\
\text { not there as intrinsic value }\end{array}$ \\
\hline & $\begin{array}{l}\text { Inconsistencies in sense of } \\
\text { connectedness }\end{array}$ & $\begin{array}{l}\text { I have less relationship with it at work } \\
\text { because I'm probably, I don't feel like I'm in } \\
\text { it in some ways }\end{array}$ \\
\hline
\end{tabular}

